\title{
SETE SONHOS URBANOS
}

João Diniz

Arquiteto

\begin{abstract}
RESU MO
$\mathrm{O}$ arquiteto sonha com uma cidade melhor através de diversas ações, e uma delas é a escrita. O texto vem através de um pensamento inconsciente, durante o sono, numa espécie de vida irreal. No final os espaços e situações vistos em algumas cenas imaginárias são os conceitos mais importantes buscados pelo arquiteto/escritor em suas proposições profissionais.
\end{abstract}

PALAVRAS - CHAVE

Arquitetura. Sonho. Urbano.

\section{SONHO I: o vôo}

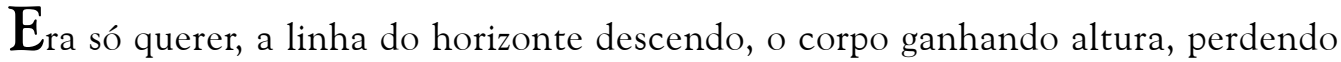
peso. A cidade transformada em um mapa, e os campos em um quadro verde de tons múltiplos.

Era necessário cuidado com os fios, com as grimpas e com as copas. Aproveitar o vento sem fazer nenhuma força seria lógico, a gravidade derrotada pelo pensamento, pela vontade.

Havia controle da velocidade ao avançar, a planta da vida passando toda abaixo. Casas, prédios, bairros, rios, um desenho com sombras lógicas, tudo conhecido e esperado, mas nunca visto deste ângulo.

Aprendi a voar com essas asas do querer, imediatas. Não será sempre, mas será possível esse prazer geográfico de, durante o sono, possuir a terra e o ar.

\section{SONHO II: A MÁQUINA}

Do computador fui direto para a cama no quarto escuro com o clarão da tela ainda impresso por trás do olhar. Deitado no breu as imagens permaneciam visíveis. De olhos fechados poderia ver bem as luzes internas da busca de um arquiteto.

Um novo projeto pedia para acontecer e aos poucos ia sendo domado e revelado nas linhas eletrônicas multicores que definiam cômodos virtuais. As respostas vinham com as dúvidas, buscando soluções, empurrando a mão, o pensamento, o mouse, gerando planos tridimensionais que inauguravam novos espaços. Com a chegada do sono o brilho não se apagou. A vibração da máquina permanecia no cérebro e as imagens continuavam a ocorrer na escuridão. 
De repente estava dentro desse desenho mental. À medida que percorria os espaços imaginários, dava-lhes forma, textura, cor. Era um jogo interativo de sentir e criar instantaneamente. $\mathrm{O}$ ato de projetar integrado ao desejo inconsciente. Um hall, uma escada, vazios, materiais, a clareza das soluções era incrível. No mesmo fluxo foi possível ganhar a rua, continuar o planejamento imediato da cidade que se transformava na mira de cada olhar ativo.

Os anos anteriores de reflexão foram suficientes para que as propostas se materializassem com eficiente clareza. Os transeuntes pareciam aprovar o recém-nascido edifício, e também as novas calçadas, praças e ruas que apareciam e indicavam o caminho do dia que despertava bruscamente.

Um relógio soa com a luz matinal. O corpo voltava ritmado aos movimentos da manhã. $O$ computador estava desligado ao lado. A cabeça um pouco confusa. Esta não havia sido uma noite de descanso tranqüila. O lápis em cima da mesa, os vários papéis impressos e riscados na noite anterior aguardavam inertes.

Sem mais demora, ligado o botão a tela se iluminou, o olhar matinal se deita sobre as imagens, com algumas modificações os desenhos buscariam encontrar as soluções antevistas há pouco no inconsciente.

\section{SONHO III: O CORPO}

Era uma névoa rubra e morna. O corpo sentia um estranho prazer epidérmico misto de constrangimento e gozo. A vontade era sair dali, correr para longe, mas havia uma provocante sensação de desafio e transgressão.

Seria apenas necessário assumir a própria imagem, encarar os olhos dos outros, dizer algo pitoresco e finalmente aproveitar a cena.

Uma estranha sensualidade dominava o momento na busca de carinho e de companhia. Tudo era rápido, a visão se detia em nada. Não era um tempo fixo, apenas o susto da própria nudez, inesperadamente defronte a todos, mistura de situação íntima e pública, pessoal e urbana. Não exibicionismo, mas sinceridade.

Se os corpos se tocassem por fora, as sensações seriam internas, uma excitação própria, um desejo de ser intenso. Os poros todos expostos ao vento e às vozes.

Eretos sonhos nas cavidades do sono. Líqüidas noites de um erotismo irreal.

\section{SONHO IV: A LIBERDADE}

De repente vejo retidos os meus movimentos ao ser parado no meio da rua por falsos policiais gentis como touros em frente à capa rubra. Meus argumentos são inválidos e eles não têm justificativa para tão descarinhosa abordagem.

Uma sensação desconfortável, um crime que não cometi, uma culpa que não é minha. Desconheço o meu delito, rejeito estas algemas. Será que existem justiça, verdade, segurança e direitos?

O mundo tão cheio de canalhas e logo eu, vítima destes brutamontes nacionais...

Serei refém da paranóia de tempos pós-revolucionários ou pós-lisérgicos? Terei que explicar atrás das grades os meus diálogos imaginários com Che, Hendrix, Lamarca, 
Morrison ou Marighella? Saberei confessar em detalhes os assassinatos, tráficos, guerrilhas, e assaltos que não cometi?

A realidade será diferente? Todos que estão realmente detidos ou livres merecem este estado? Continuo aqui constrangido em via pública, uma discussão interminável, um assunto que dura toda noite até que me sinta desperto deste constante pesadelo público.

\section{SONHO V: o SOM}

Era quase um silêncio noturno, mas mecânicas melodias percorriam o ar. Um trem apitava ao longe, alguns motores passavam velozes, distantes e irreconhecíveis palavras dialogavam lamentos, alguma ave com seu canto aéreo anunciava o dia.

Sons dispersos, desconexos, de repente harmonizavam-se, confundiam-se, ritmavamse. Alguma outra voz era introduzida num súbito grito. Aquela sinfonia na madrugada antecedia o diurno murmúrio urbano propondo uma obra aberta que duraria o quanto necessitasse.

Sentia-me um maestro, um compositor, poderia até arriscar uns versos para o coral de buzinas cantar esta suíte matinal de ruídos. A vontade maior era levar aquela performance espontânea para o mundo da vigília.

Naquele orgasmo sonoro sabia-se que em breve tudo estaria perdido. A cidade voltaria aos seus mesmos rugidos insistentes, cansativos, estressantes, o dia se estabeleceria num crescendo dissonante.

Restaria apenas manter o sonoro instante por mais um pouco, propor um gran finale, uma inesperada apoteose, antes do despertar.

Agora apenas texto talvez pudesse contar algo desta aventura musical...

\section{SONHO VI: A MONTANHA}

A vontade de conhecer o mundo ia sendo satisfeita naquelas noites de sono tranqüilo. Os sonhos eram roteiros de viagens e iam revelando locais, sugerindo para a memória desperta abstratos cartões postais onde desfilavam, quase reais, lugares, pessoas, e até sons e odores. Cidades e países com suas diferentes luzes iam compondo aquele álbum mental de momentos inéditos, e inesperadas descobertas.

A pequena ilha distante e sua alegre cidade costeira eram recorrentes nas dormidas mais confortáveis, revelando nitidamente seu mar profundamente azul; suas areias, pedras e faces intensamente negras; um idioma composto por um caleidoscópio de nacionalidades; e seus alimentos desconhecidos e saborosos.

O que mais chamava atenção era a animação da pequena metrópole. O final dos dias trazia a música e a dança, os cabarés exalavam calor e satisfação, as ruas repletas cantavam a riqueza da alegria de viver uma liberdade desenhada numa ousada política de intercâmbios e protestos.

As visitas oníricas àquela cidade permitiam reconhecer seus belos edifícios, mas a visão mais impressionante era a grande e misteriosa montanha que se impunha majestosa sobre toda a ilha e que num último sonho estava estranhamente envolta por uma bruma de cinzas e pedras que jorravam sobre as praias e telhados turvando a visão de todos. 
Quando fui convidado a conhecer Saint-Pierre da Martinica, no arquipélago das Antilhas, ressurgiram claras as lembranças daqueles distantes sonhos insulares; por incrível coincidência iria talvez rever os perdidos locais presentes naquelas noites de sono.

Ao chegar lá pessoalmente, o sentimento de estar retornando ao lugar era muito forte. As ruas, as praias e a geografia pareciam familiares, mas havia uma diferença fatal: as principais construções eram ruínas de pedras escuras.

Todos ali comentavam que há mais de cem anos a grande montanha havia explodido. $\mathrm{O}$ vulcão soterrara quase todos os seus habitantes e aquela ex-bela cidade, que desde então lutava para encontrar sua antiga felicidade e brilho.

\section{SONHO VII: A LENDA}

Naquela noite a imagem ocorreu numa breve nitidez. Ao dobrar uma esquina de Belo Horizonte estou fora do tempo e me vejo numa viela medieval. A luz das tochas e os trajes revelam a súbita presença de uma outra época. Numa confusão de idades chego ao passado.

Ao lado da igreja gótica, um templo grego. Na larga praça renascentista, inscrições pré-históricas e um jardim zen com plantas tropicais. Algumas odaliscas dançam o samba, cortesãs cantam mantras safados enquanto uma orquestra de cordas afina os primeiros acordes de uma trágica suíte.

Um cavalo branco cruza as trevas num agouro desconhecido de datas e fatos. Mais além estão as caravelas. Seus mastros tremulam no breu e uma frenética ação vem de dentro; com as velas içadas zarpariam de manhã num prenúncio de descobrimentos.

As tavernas iam silenciando enquanto a areia passa pelo funil de vidro e os pavios queimam tremulantes. Alguns vultos se apóiam uns nos outros. Uma coruja cruza o céu sublinhando com suas asas a crescente lua.

Passos sobre pedras, botas rudes traçando caminhos humanos. Envolto em uma capa negra, corro insone. O lençol é um porto imaginado, a segurança invertida de um sonho.

Ao descer as escadas, o caos. A estação do metrô está repleta de fumaça e chamas. As pessoas apavoradas saem de uma bruma de terror, entre alarmes, estampidos e gritos; muitas sirenes interrompem o sono de todos.

Que estranha forma de acordar...

\section{4}

\section{A B STRACT}

The architect dreams a better city throught many utopic actions, and one of them is the writing. The text comes along with the inconscient thinking while sleeping in a kind of unreal life. In the end the spaces and situations viewed in some imaginary scenes are the most important concepts searched by the architect/writer in his professioal proposals.

\section{KEYWORDS}

Architecture. Dream. Urban. 